\title{
El arbitrismo en el gremio minero novohispano o la representación de J. de la Borda y J. L. Lazaga (1767). (Documentos)
}

\author{
Frédérique Langue \\ Centre National de la Recherche Scientifique. \\ París, Francia
}

A diferencia de la célebre representación dada a conocer en 1774 por J. L. Lazaga y J. Velázquez de León, el texto de 1767, redactado por Lazaga y el conocido minero y empresario José de La Borda, no pasó a la posteridad. De ahí la publicación de este documento original que permite valorar la evolución experimentada en estos años de crisis por la minería novohispana, tanto en sus aspectos económicos, sociales y tecnológicos como institucionales. No dejó de influir, en efecto, en la creación de lo que llegó a ser el organismo representativo del gremio minero, el Tribunal de Minería (1777), en el que uno de los autores desempeñará precisamente un papel relevante.

Hay textos que permanecen en la memoria del historiador, por más que tengan precursores que presenten un interés similar. La suerte e inevitable subjetividad de un recopilador, que no se trata aquí de poner en tela de juicio - junto a un contexto histórico o ideológico difícil de eludir también- determina en muchos casos el destino de estos manuscritos. Tal fue el caso de la representación de J. L. Lazaga y J. Velázquez de León (1774), dada a conocer en 1938 por L. Chávez Orozco, y pasada a la posterioridad en cuanto los especialistas de la minería mexicana no dejan de mencionarla. ${ }^{1}$ Otra suerte corrió un texto anterior, tan rico por los datos que proporciona y la argumentación adelantada.

1 Lazaga, Juan Lucas de; Velázquez de León, Joaquín: Representación [1774], reproducida por Chávez Orozco, Luis: La minería en la Nueva España a postrimerías del siglo XVIII, Documentos para la Historia Económica de México, vol. XII. México, 1938, $\mathrm{X}-38$ págs. 
De ahí la elección nuestra de dar a conocer este primer texto, que permite explicitar en una gran medida la representación de 1774, evidenciar los elementos de continuidad en el discurso minero y la problemática subyacente (en unos decenios de crisis para la minería novohispana, especialmente la zacatecana, representada por los dos diputados y apoderados generales, incluso antes de que se formalizara, a través de la creación del Tribunal de Minería, la actuación de los "diputados" de los reales de minas), a la par que precisa la actuación de los dos mineros. Se conoce relativamente bien la vida y obra de Lazaga, uno de los inspiradores y directores - con Joaquín Velázquez de León- del organismo estructurador de la minería novohispana de fines del siglo XVIII, el Tribunal de Minería. J. L. de Lazaga era además, dato menos conocido por los especialistas del tema minero, minero-hacendado en la región de Mazapil, en el noroeste de la futura intendencia de Zacatecas. De ahí la recurrencia de las referencias a la situación de Zacatecas a lo largo de ambos textos. En cambio, se conoce a José de la Borda, "primer minero del mundo" según la apreciación del jurista Francisco Javier Gamboa, como práctico y perito en la materia más que como autor de representaciones dirigidas a las autoridades virreinales o a la Corona, en otros términos como arbitrista. Esta referencia a estos precursores de los economistas modernos y la elección nuestra de este calificativo para designar esa actividad tan peculiar desarrollada por los mineros novohispanos, y en especial, por los zacatecanos obedece a una filiación: recoge la tradición peninsular, tan celebrada o vituperada según los momentos pero altamente reconocida, de los consejeros en materia económica y fiscal que alcanzan pleno reconocimiento en el Siglo de Oro. Por los temas tratados y las propuestas adelantadas y el éxito de las mismas, no podemos sino reconocer esta herencia hispánica, identificada en otras regiones de América, Perú, por ejemplo; punto pasado por alto por los especialistas de otras áreas. ${ }^{2}$

2 Fuentes Bajo, María Dolores: Las últimas manifestaciones del proyectismo en la minería peruana, "Historiografía y Bibliografía Americanistas", vol. III, n. o 1, Sevilla, 1986, págs. 3-32. 
El porqué de esta postergación en el caso de este documento, localizado, quizá se deba achacar a la figura indecisa e imprecisa de J. de la Borda, minero de primera categoría pero sujeto algo controvertido de la Corona española (véase la polémica ulterior acerca de su origen francés). Lo mismo sucederá con sus sobrinos los Pemartín, implicados en los tenebrosos años post-1789 en un proceso del Santo Oficio y puestos a salvo e "inocentados" por sus colegas zacatecanos. Esta es una hipótesis nuestra, que tendría por supuesto que ser comprobada pero que presenta cierta validez en el contexto que señalamos. ${ }^{3}$

Estas reflexiones permiten abordar de hecho la casi totalidad de los temas asociados a la minería americana, en su vertiente novohispana, aunque con fuerte orientación fiscal. Respecto a la ciudad de Zacatecas y a lo que podemos considerar como su "entorno minero" (por referencia al "entorno agrario" que se suele tomar en cuenta en el caso de las regiones agrícolas) ${ }^{4}$, subrayan de entrada el papel organizador del centro minero de donde se envían de manera significativa avíos y a donde llegan las correspondientes platas (no solamente para quintar sino como contrapartida de los referidos créditos). Tuvimos la oportunidad de estudiar detalladamente el funcionamiento del crédito minero en la comarca zacatecana. Por lo tanto remitiremos a los estudios especializados en esta temática y nos conformaremos con señalar, a favor del dato suministrado por los autores, que el radio de acción de los aviadores zacatecanos -eran en ciertos casos "banqueros de la plata" - desde fechas muy tempranas abarcaba la casi totalidad del virreinato, de la ciudad de México (desde donde organizaban en realidad sus negocios mineros, mercantiles y agrarios) a la actual región de Chihuahua, incluyendo

3 Brading, D. A.: Mineros y comerciantes en el México borbónico, 1763-1818, México, 1975 (Cambridge University Press, 1971); sobre el temor suscitado por la Revolución francesa y sus avatares en Nueva España y más particularmente en Zacatecas, véase nuestro trabajo, Los franceses en Nueva España a finales del siglo XVIII. Notas sobre un estado de opinión, "Anuario de Estudios Americanos", vol. XLVI, Sevilla, 1989, págs. 219-241.

4 Van Young, Eric: Hacienda and Market in Eighteenth-Century Mexico: the Rural Economy of the Guadalajara Region, 1675-1820, Berkeley, 1981; del mismo autor, Estructura agraria y rebeliones populares de la Nueva España, 1750-1821, México, 1992. 
la rica zona agrícola del Bajío. Basta con recordar que la familia de los Campa Cos (condes de San Mateo Valparaíso, al mismo tiempo mineros y hacendados terratenientes) controlaba en este orden de ideas y con una eficiencia pocas veces lograda en la historia empresarial de Nueva España, el abasto de no pocos centros mineros novohispanos -incluyendo a Zacatecas - papel retomado unos decenios más tarde por sus parientes los marqueses de Jaral de Berrio. En otros términos, se trata de la formación de un espacio económico que ciertos autores no vacilan en ejemplificar con el término de "mercado".

Respecto a los factores determinantes de la producción, los dos expertos aluden con insistencia a tres de las causas que determinan la decadencia de la minería novohispana: la falta de avíos, tanto los capitales como materiales e insumos necesarios para la labor minera como el azogue, la pólvora, el hierro, maíz, velas, sogas, etc... (no pocos virreyes lamentarán la ausencia de mineros "capitalistas", con riquezas suficientes como para invertir -y posiblemente perderlas- en las minas) y otras dos causas más propias de centros mineros antiguos como Zacatecas: el agotamiento de las vetas y la disminución de las leyes del mineral, a las que se podría añadir en el mismo orden de ideas los gastos crecientes ocasionados por este tipo de explotación (desagüe y extracción), especialmente cuando se llega a unas profundidades prohibitivas para las inversiones posibles (profundidades de 360 varas no son excepcionales en las minas visitadas por Humboldt). Una causa anexa -que no se da en todos los reales de minas novohispanos- es la inseguridad provocada por la presencia de indios nómadas que atacan reales de minas, haciendas y convoyes de plata (carácter fronterizo de la región zacatecana, ubicada en la llamada "gran chichimeca", que perdura hasta principios del siglo XIX). Ahora bien, el factor clave del éxito, pero también de la decadencia de la minería, sigue siendo el azogue, como lo indicó igualmente Humboldt al reseñar los pormenores de la legislación sobre este ingrediente. ${ }^{5}$

5 Humboldt, Alejandro de: Ensayo político sobre el reino de la Nueva España, México, 1978, págs. 382 y ss. 
La causa más determinante según los dos mineros, sigue siendo en efecto y para ese momento la de los insumos, sumamente costosos en el caso de los monopolios de la Corona (estancos) que son el azogue y la pólvora (aunque una problemática semejante se planteará ulteriormente con el salitre y la explotación de las salinas, especialmente en el sureste de la futura Intendencia de Zacatecas, en el Peñol Blanco).

Asimismo abordan las consecuencias de este tipo de crisis minera: la emigración de la mano de obra hacia unos centros mineros más favorecidos por las bonanzas; a ese respecto, tuvimos la oportunidad de poner de relieve el hecho de que, siendo casi siempre invertidas las curvas de producción de Zacatecas y de Sombrerete (sede de otra caja real), la mano de obra faltante en un centro minero se encuentra de manera casi sistemática en el otro, siguiendo los ritmos de la producción local (esta inversión se debe entre otras causas a la naturaleza distinta de los minerales, tratados por azogue en Zacatecas, y más bien por el procedimiento de la fusión en Sombrerete). ${ }^{6}$

Por último, la problemática del azogue nos lleva a la de los gravámenes que afectaban la producción minera, de las minas mismas hasta la Casa de Moneda: hasta el $26 \%$ del valor total, lo que explica el éxito de las exenciones fiscales concedidas en el último tercio del siglo XVIII, a favor principalmente, de los mineros zacatecanos. La primera gracia concedida en este sentido por la Corona lo fue precisamente a favor de José de la Borda (real cédula del 12 de marzo de 1768) para la restauración de la célebre mina de la Quebradilla.

De ahí la característica de los centros mineros, la de construir unos enclaves que obedecen a uno ritmos propios, sin por eso dejar de ser afectados por crisis de carácter más general, como lo fueron por ejemplo las crisis climáticas y agrícolas de $1785-1786 .{ }^{7}$

6 Langue, Frédérique: Mines, terres et société à Zacatecas (Mexique) de la fin du XVIle siécle à l'Indépendance, París, Publications de la Sorbonne, 1992, para los datos relativos a Zacatecas y al ordenamiento de la minería novohispana, salvo indicación de otra fuente.

7 Van Young: La crisis del orden colonial..., págs. 429 y ss.: "Haciendo historia regional. Consideraciones metodológicas y teóricas". Trata las regiones mexicanas y la teoría del "embudo" en vísperas de la Independencia. 
Zonas aparte en lo económico, relativamente favorecidas e influyendo en alto grado en las zonas circumvecinas, y también en lo social si consideramos las modalidades de la "reproducción" de las grandes familias e incluso de la aristocracia minera, que tiene como consecuencia el control de vastos sectores de la minería regional por determinados clanes familiares.

Una endogamia social y nobiliar: en lo social, subraya una de las características de las élites mineras zacatecanas, el entroncamiento de los recién llegados con las antiguas familias de los conquistadores. Entre ellos, el conde de Santiago de la Laguna (segundo del título), José de Rivera Bernárdez, autor en 1732 de una descripción de la ciudad y de un compendio de los hechos más notables sucedidos en el Cabildo zacatecano desde la fundación de la ciudad. Una élite cuya riqueza - y títulos nobiliarios- descansaba en las fortunas mineras para las primeras generaciones pero que, salvo contadas excepciones, se reconvertía para asegurar y preservar este mismo estatuto social, en las actividades derivadas de sus haciendas de campo, comportamiento que J. Kicza puso de relieve con modalidades muy similares para la ciudad de México, donde estaba instalada además la élite principal del virreinato, especialmente los grandes mineros zacatecanos (fue el caso de J. L. de Lazaga, si consideramos los cargos que llegó a ocupar en la capital virreinal). ${ }^{8}$

El "arte de lo metálico" o la ciencia de los metales: los necesarios conocimientos, problema que se plantearán precisamente los fundadores del Tribunal de Minería al contemplar el establecimiento del Seminario y del Colegio de Minería. Y de la misma manera al apelar - sin mayor resultado, lo que pone de relieve la buena adaptación de las técnicas locales a la naturaleza del mineral- a los peritos alemanes invitados en 1789 a recorrer las minas de Sombrerete, por aquel entonces propiedad de la familia Fagoaga, marqueses del Apartado.

En cuanto al porvenir de estas observaciones, de esta representación, se puede subrayar lo siguiente: la creación en 1777 de un

8 Kicza, John: Empresarios coloniales. Familias y negocios en la ciudad de México durante los Borbones, México, 1986. 
organismo representativo del gremio minero que hace de los mineros unos actores políticos, por no decir un grupo de presión, ${ }^{9}$ la adopción de medidas fiscales de tipo general (disminución del precio del azogue, siendo precisamente una de las primeras medidas tomadas por el visitador José de Gálvez la rebaja del azogue en 1767 hasta 62 pesos el quintal - la segunda rebaja, hasta 42 pesos el quintal, interviene en 1776-, y más adelante de la pólvora) o particular (exenciones fiscales, siendo José de la Borda, como lo señalamos, uno de los primeros benefiçiados por estas medidas). En todo caso, esta primera representación de los mineros zacatecanos de finales del siglo XVIII parece haber desempeñado un papel de catalizador, al propiciar una reflexión más orientada hacia la temática fiscal de parte de los mineros novohispanos, la cual aparece a todas luces en el segundo texto, tema amplificado sin embargo por el contexto de crisis agudo que sigue rodeando la publicación de la representación de 1774.

9 Flores, Eduardo; Velasco, Cuauhtémoc: Minería y poder políico en México 17701856, "Historias", núm. 5, México, enero-marzo de 1984, págs. 33-51; para una buena síntesis de las relaciones entre el Estado y la minería, véase Velasco, C.; Flores, E., y otros: Estado y minería en México (1767-1910), México, 1988, 1. ${ }^{\text {a }}$; Langue, F.: Mineros y poder en Nueva España. El caso de Zacatecas en vísperas de la independencia. "Revista de Indias", vol. LI, Núm. 192, Madrid, 1991, págs. 327-341. 


\section{Documento *}

Copia de la representación hecha al Exmo. Virrey de este Reino, Marqués de Croix, por don Juan Lucas de Lazaga y don Joseph de la Borda, como apoderados generales de toda la Minería de estas Provincias de Nueva España, proponiendo varios puntos, medios y providencias útiles y económicas, al mejor fomento, y restablecimiento de tan favorable, y principal ramo, al común del estado de la Monarquía, y del Comercio en general. México, 2 de noviembre de 1767.

\section{Excelentísimo Señor:}

Don Juan Lucas de Lazaga, Regidor perpetuo de esta Nobilísima Ciudad, Juez Contador de Menores y Albaceazgos de ella, y Minero en el Real del Mazapil, ${ }^{* *}$ y don Joseph de la Borda, Minero en los Reales de Taxco, Tlalpujahua y Chontalpa, a nombre de toda la Minería de este Reino de Nueva España, vamos a hacer presente a Vuestra Excelencia con la debida sinceridad, el lastimoso estado en que se halla, y a proponer a su superioridad los medios que nos parecen más conducentes a su recobro, con la bien fundada esperanza de que la madura atención, y conocido zelo de Vuestra Excelencia tomará las providencias más oportunas, en un negocio de tanta entidad para el común de la América e intereses del Real Erario.

Aunque no sería fácil formar un entero concepto de la presente lamentable caída de la Minería sin la experiencia y examen ocular de todos los Reales de Minas, o por lo menos un informe circunstanciado del principio, progreso, y estado actual de cada uno de ellos, sin embargo lo que de todos generalmente diremos, bastará para que Vuestra Excelencia se haga una idea suficiente de la urgentísima necesidad del remedio en que se hallan; protestando ante todas cosas, que de lo que afirmaremos en el asunto, fuera de ser notorio en esta Ciudad, como que de ella salen los avíos inmediata u originalmente para todos los Reales de Minas, y a ella se vienen a reconocer todas las platas que producen, de suerte que no puede ignorarse su estado en el comercio. Ofrecemos dar (caso que vuestra

* AGI, México, 2.235.

** Subrayado en el texto. 
Excelencia lo juzgue necesario) todas aquellas pruebas que la prudencia de las Leyes ha juzgado eficaces, para justificar los hechos importantes. Tampoco dejaremos de decir, que de los dos que hablamos, el primero es dueño de unas Minas que solamente producen Metales de fundición y se han trabajado sin la menor intermisión desde el año de 1560. El segundo es el más antiguo de los Mineros del Reino; ha trabajado siempre con gran corriente, en diversos Reales de Minas, y por la mayor parte con el beneficio de Azogue, sin haber dejado de usar del de fuego, siempre que ha sido necesario; está bastantemente acreditado en este Reino (y aun en otros) así por la variedad de su fortuna, como por la magnitud de sus trabajos, de manera que, entre los dos, debemos tener toda la inteligencia, práctica necesaria, para hablar con seguridad en esta materia.

Los Reales de Minas conocidos y trabajados en este Reino son entre grandes y pequeños ciento $y$ doce; pero de este número se hallan enteramente abandonados los cuarenta y dos, unos por su esterilidad y escasez de Metales, o porque aunque los produzcan con abundancia, son de Leyes bajas y hasta ahora incosteables; otros por la falta de alimentos y de comercio; muchos por las continuas irrupciones de los Bárbaros; pero la mayor parte, por causa de las aguas que han invadido sus Minas. Y aunque no siempre es imposible libertarlas de este inconveniente, siempre es costoso, y como no se puede tener seguridad de sacar Metales tan ricos que sobre los derechos y el alto precio del Azogue puedan también cubrir los costos de su extracción y los del desaguie y habilitación de la Mina, viene a ser este justo temor, y desaliento, la causa principal del abandono. De los otros setenta, muchos apenas merecen no agregarlos al número antecedente. En los más antiguos y principales se hallan del todo inhabilitadas y desiertas las mejores Minas, sobre vetas matrices, que en otro tiempo hicieron la riqueza de ellos y dieron motivo a su establecimiento; solamente se trabajan algunas otras en cintas de menos formalidad y duración. Aun los que se han descubierto de treinta años a esta parte no se hallan en aquel corriente que debía corresponder no a la opulencia de sus principios, sino a una regular mediocridad. Y para que Vuestra Excelencia conozca con mayor especificación la verdad de lo que acabamos de decir, expondremos por menor la presente lastimosa constitución de la Ciudad, y Real de Minas de Zacatecas, bien que por ser uno de los de mayor fundamento y nombre en la Nueva España, famoso aun en los Reinos extranjeros, es el ejemplo más ilustre de que puede usarse en el asunto.

Fundose esta Ciudad en 1546, en 23 grados de latitud boreal y 277 de longitud, a más de 80 leguas al noroeste de México. Su situación es la raíz de una montaña que era ante mural de los Chichimecas y hacía ne- 
cesaria así una población que sirviese de freno a las hostilidades de estos Bárbaros y facilitase la entrada a todo el Reino de la Nueva Galicia. La brevedad con que se fundó y se aumentó en muy pocos años se debió sin duda a la riqueza de sus Metales cuyas vetas tienen en aquella parte una de las principales matrices del reino Mineral de la Nueva España. Su extraordinaria riqueza no pudo esconderse a sus conquistadores, acostumbrados a encontrarla en casi todas sus anteriores conquistas, y ella misma no podía menos que convocar para sus logros a todos aquellos que tuvieron noticia y proporciones para conseguir allí su establecimiento.

Este fue de suerte, que en 1585 tuvieron ya sus Pobladores, méritos suficientes para impetrar y conseguir en Cédula de Felipe Segundo, dada en Monzón a 8 de octubre el título de Ciudad de Nuestra Señora de los Zacatecas, y por otra en San Lorenzo a 20 de julio de 1586 se le concedió el de Muy Noble y Leal Ciudad y la Merced de escudo de Armas, especialmente honrado con el nombre de la Magestad, y brillante con diversos blasones de plata que simbolizan lo mucho que hasta entonces havían producido aquellas Minas en servicio y gloria de su Reinado. Y es un gran argumento, de la primera opulencia de este Mineral, lo que lograron sus primeros conquistadores. El principal de ellos, Joanes [Juan] de Tolosa, casó con la Señora Doña Leonor Cortés Moctezuma, hija del glorioso capitán Hernán Cortés, y nieta del Emperador Moctezuma. Otro de ellos, Diego de Ibarra, casó con la hija de un virrey. Juan de Oñate, fue primer Adelantado del Reino de Nuevo México y todos ellos tuvieron mucho esplendor, e increíbles riquezas, como puede verse en el Nobiliario de Haro.

En el año de 1562 había en Zacatecas, 35 haciendas de beneficio de Azogue, y casi otras tantas de fundición, cuyo corriente mantenían muchas más Minas principales, sobre las vetas de San Bernabé, Albarrada, Pánuco y otras capitales. Prosiguió el auge de este Mineral hasta mitad del siglo décimoséptimo, y cesando entonces, se mantuvo en estado de mediocridad hasta 1732, en que comenzó su precipitada decadencia. En este año no se hallaban ya más de 24 haciendas de beneficio de Azogues, con 97 Ingenios de moler Metales, 20 Haciendas de fundición, y algunas tahonas, hornos, muflas y otros pequeños artes, par uno y otro beneficio, en el cual se. consumían anualmente en salarios y jornales, géneros y efectos de Minería, fuera de los Azogues (de que hablaremos después) más de un millón y seiscientos mil pesos, como puede verse calculado por menor y con la correspondiente justificación, en el Libro de la Historia de Zacatecas, escrita por el Conde de La Laguna, antiguo vecino y famoso Minero de aquel Real. El consumo de víveres, según expresa el mismo autor, pasaba de 85.000 fanegas de maíz, y de 20.000 
de harina, y así de lo demás a proporción. De suerte que entraban cada año de distintas casas en aquella Ciudad, 6.205 carretas, y conforme a este consumo se estimaba su Población por más de 50.000 personas, y su comercio se componía de más de 60 tiendas grandes de ropas, y ciento $y$ cincuenta de otras especies.

Por los Libros de aquellas Cajas Reales, se percibe que producía sólo en los derechos de plata 257.350 pesos cada año, hasta el de 1732 , y en 180 que se contaban entonces desde su conquista, había producido por este título cuarenta y seis millones trescientos treinta y tres mil pesos. A los Mineros les quedaba libre en cada año un millón ochocientos sesenta $y$ seis mil. ciento y sesenta y seis pesos. Y en los 180 años, 335.902 .880 pesos. El consumo de Azogues rendía a Su Majestad en cada un año 13.550 pesos y en los 180 veinte y cuatre millones doscientos treinta y nueve mil pesos.

Veamos ahora el estado actual de Zacatecas. Por las diligencias que presentamos para justificación de estos puntos, consta por declaración contexte de doce testigos de la mayor excepción, vecinos antiguos de aquella Ciudad, y del informe del Procurador General, Corregidor y Alcalde ordinario de ella, que no se hallan en corriente, más que cinco haciendas de beneficio de Azogue y dos de fuego. Que casi todas las Minas están abandonadas y desiertas, que apenas se verifica algún comercio, y que el consumo de víveres a sido en estos tiempos menos de la mitad, de lo que solía ahora 20 ó 30 años; pues en los próximamente pasados, apenas ha llegado a cuarenta mil fanegas de Maíz. Finalmente por la certificación de Oficiales Reales (que asimismo presentamos) consta que habiendo sido el consumo de Azogues, en un quinquenio, contado desde 1749 hasta 1753 la cantidad de 7.646 quintales 49 libras 11 onzas, en este último quinquenio desde 1760 hasta 65 sólo se han expendido 3.208 quintales 50 libras. De manera que en 30 años, ha perdido esta Ciudad más de la mitad de su población, y nueve de las diez partes del corriente de su Minería. Con que en un medio siglo, habrá llegado a su última ruina, subsistiendo las mismas causas. Este es el deplorable estado del famoso Mineral de Zacatecas, y este mismo es el que tienen oy Chihuahua, Sombrerete, Pachuca, El Fresnillo, Los Asientos de Ibarra y en una palabra, casi todos los del Reino.

Es muy fácil advertir los graves efectos y pésimas resultas que se derivan de la ruina de la Minería. El primero es la despoblación y siendo este el gran mal de la América, y aun de toda la monarquía, ya se ve, que debe evitarse aun en los lugares de menos consideración que los Minerales. Pero cuanta sea la de todos, por ahora conjeturarse con el mismo ejem- 
plo de Zacatecas, porque es cierto, que si como ha perdido de cincuenta mil personas, las veinte y cince, éstas hubieran permanecido, no sólo subsistiera el mismo número de personas de cincuenta mil personas, sino el aumento correspondiente a su propagación, que pudiera computarse por lo menos de quince mil. Debiera pues tener ahora sesenta y cinco mil y así teniendo 25 la pérdida ha sido de cuarenta mil personas. Aunque ésta no sea tan absoluta, que del todo falten otros tantos vasallos a la Monarchía. Pero es cierto que pasándose de unos lugares a otros, estrechan la dominación, desiertan el terreno cultivado y aumentan en otra parte el numero inútil de consumidores y miserables. Fuera de que el despueble principal consiste, en que por la miseria de los lugares, disminuye el número de los casamientos y con él, el de los pobladores, dejando por esto de nacer los que debían haber nacido. Ni se quedan las familias en los lugares cercanos, porque en ello es contagiosa la calamidad de los Reales de Minas. Pues siendo éstos, como unas cabezas de Provincia, se mantienen siempre, no ocupándose más que en la Minería y en llevar los frutos y efectos de la comarca, cuyos habitantes tampoco tienen otro empleo que el de labradores y ganaderos, y así es necesario que faltando en los Reales de Minas, los individuos, les falten a los demás lugares, otros tantos consumidores de sus frutos, no teniéndoles quenta llevarlos a parajes más distantes, donde abundan los que han menester, a menos precio del que aquellos necesitaban. Así dejan de cultivar sus tierras, como es notorio, y se verifica en ellos por estas causas, la propia miseria, causándole al Público, y a la Monarquía, los mismos daños.

El segundo efecto es, que con la Gente de los Reales de Minas, se pierde también la pericia de la Minería. El saber labrar una Mina, logrando todo lo que tienen de útil, y dejando en su firmeza la montaña, seguir la dirección de una veta que se emborrasca o se extravía; dar un tiro, un socavón, o contraMina, y sobre todo distinguir lo Metálico de lo no Metálico y lo útil de lo inútil. Es un arte que se ha de aprender por una larga experiencia, para que se puedan conseguir en él algunos conocimientos seguros. Y ¿qué diremos del beneficio de los Metales, esto es el proceso de operaciones con que se experimentan las piedras? Esta es una Ciencia (si puede llamarse así) que no cede en dificultad a ninguna otra. Los Orientales y los Alemanes y otras Naciones siempre exercitadas en la Metalurgia no blasonan de su perfecta inteligencia. En la América, después de doscientos años, tenemos cada día, nuevos motivos para la admiración y desengaño: el perito en un Real de Minas no puede lisonjearse de que tendrá la misma felicidad en otro; aun en una propia Mina, se experimenta una maravillosa variedad y semejantes artes sólo se aprenden pot imita- 
ción y se conservan tradicionalmente; pero los Padres, despechados de su ingrata profesión, aplican a los hijos a otro oficio, y por lo menos, en los nietos de los más peritos, ya no se encuentra la menor noticia de la Minería, como puntualmente se está verificando en los Minerales abandonados. De suerte que si alguna vez, se pretende instaurar en ellos el trabajo de alguna Mina, es necesario llevar Gente de otra parte, con sumo costo y dificultad. Este es un gran mal; pero peor sería que se perdiese enteramente en el Reino la memoria de este ejercicio porque no fuera posible el repararlo, como parece que no lo ha sido, en la antigua España.

El tercer efecto es, que de la despoblación de los Reales de Minas, se sigue también la pérdida de los edificios públicos y particulares y de las Haciendas e ingenios de Metales, de que se componen. Ya hemos visto, que en Zacatecas, de cuarenta y cuatro Haciendas, de uno y otro beneficio de Platas que se verificaban en el año de 1732, se han arruinado las treinta y siete, y ha perdido por consiguiente el Público y el estado, el valor e importancia de este gran número de fincas que así como los templos y edificios urbanos de los lugares, les han costado a los Mineros crecidas sumas de dinero. Y aunque con alguna disminución, valen mucho, mientras se mantienen parados, y hay quien los ocupe; pero eso mismo dejan de valer en el caso de su ruina con que otro tanto pierden el Público, Ciudades, Villas y Pueblos muy considerables, la Nueva España, y la Corona: detrimento que se debe estimar en muchos millones.

También es digno de particular atención que estando Zimapán, Chihuahua, Zacatecas, y casi todos los Reales de Minas de la tierra adentro, situados en unas montañas, que en un tiempo fueron madriguera de los Bárbaros, volverían con facilidad a serlo, siempre que aquellos Paizes se hallasen despoblados; pues se sabe, que su osadía no tiene más freno que las Poblaciones bien formadas, y aun no siempre suelen respetarlas, como se ha experimentado en San Felipe, El Real de Chihuahua, y otros lugares de la frontera. Lo que es tanto más digno de temerse cuanto con facilidad podían reestablecer las Poblaciones, y ocuparlas o habitar la Minas, con lo que haciéndose más fuertes, sería su estirpación acaso más dificultosa, de lo que fue su conquista, y aun con el tiempo podían invadirnos, y reconquistar lo bien poblado o causar otros daños al estado y al Público, incomparablemente mayores que los que al presente causan. Y despobladas las minas y sus comarcas, por lo menos volverían a hallar la Barbarie y la idolatría aquellos lugares ilustrados antes con la Luz del Evangelio y consagrados con la presencia Real del mismo Jesu Christo. Y ésta es una pérdida de superior clase, infinitamente más sensible al Gobierno católico que todas las referidas. 
Podríamos hacer, Señor Excelentísimo, otras muchas reflexiones sobre otros perjuicios que han resultado de la decadencia de la Minería, y los inumerables que deven temerse si prosigue; pero estudiamos en la brevedad y quisiéramos decirlo todo con laconismo. A la importancia de este asunto, deve imputarse la culpa de nuestra difusión. Y ella misma no nos permite pasar en silencio la gran pérdida que en dinero efectivo han hecho el Público y el Real Erario, indicando la de los Reales de Minas, con el único referido ejemplo del de Zacatecas.

Si consideramos a este Mineral en el corriente en que se mantuvo con mui poca variedad por 186 años, esto es desde 1546 hasta 1732 en que comenzó su decadencia por las causas que después diremos, no hay duda que será un estado medio en que podía haberse conservado hasta ahora y conservase siempre, mediante el alivio y fomento, que desde este tiempo comenzó a necesitar. $\mathrm{Y}$ así, el cálculo fundado sobre el producto anual que entonces daba, será muy prudente y no tendrá nada de fantástico. Este producto era de un millón ochocientos sesenta y seis mil pesos en cada año, según lo que consta por los Libros de aquellas Cajas Reales y deberá constar en éstas. Con que en los 34 que han corrido desde entonces, hubiera producido a favor de los Mineros y vecinos sesenta y tres millones cuatrocientos cuarenta y cuatro mil pesos; y restando de aquí la quinta parte de aquella suma que es más que lo que efectivamente ha producido esta Minería en dichos 34 años, han perdido los Mineros y por consiguiente el Público, cincuenta millones setecientos cincuenta y cinco mil y doscientos pesos. Y considerando cuanto debía haber aprovechado el bien común de la América y el de toda la Monarchía en los giros de comercio de esta cantidad, se vendrá en conocimiento del estupendo perjuicio que ha causado la ruina de Zacatecas.

Es bien claro, que estos perjuicios del Público y del estado, nesesariamente ocasionan otros en el Real Erario. Porque manteniéndose aquellas Minas como se hallaban en dicho año de 32, debían haber producido de derechos de Plata en estos 34 a razón de doscientos cincuenta y siete mil pesos en cada uno, ocho millones setecientos treinta y ocho mil pesos que deduciendo una quinta parte, que es más de lo que efectivamente han producido, ha perdido la Real Hacienda seis millones novecientos noventa mil y quatrocientos pesos sólo en los derechos. Acerca del consumo de Azogues, en lo certificado últimamente por Oficiales Reales de aquellas Cajas, verá Vuestra Excelencia que estos últimos diez años ha bajado de siete mil seis cientos cuarenta y seis y medio quintales a dos mil ochocientos cuarenta y tres, y a este respecto desde el año de 1753, en que se cumplió el primer quinquenio, certificado hasta el pasado de 66 , se han 
dejado de expender más de diez mil quintales que importan más de ochocientos mil pesos; de que rebajando trecientos mil por el costo, y conducción de Azogues, ha perdido la Real Hacienda, sólo en estos 12 años, quinientos mil pesos; y en los treinta y cuatro muy cerca de millón y medio.

Ultimamente de aquellos cincuenta millones, que como dijimos antes debía haber producido Zacatecas en estos 34 años a favor de los particulares, hubiera logrado la Real Hacienda la tercia parte que es diez y seis millones seiscientos sesenta y seis mil seiscientos sesenta y seis y dos tercios de pesos. Porque estos cincuenta millones por último habían de haber ido a parar a la Europa por la vía de España, como precio de su equivalente en efectos de comercio; y ya se ve, que los derechos que en esto utiliza la Real Hacienda son más de un tercio, pues se regulan a un cuarenta y cinco por ciento, de manera que sumando las referidas tres partidas del Real Erario, componen 25 millones ciento y cincuenta y siete mil sesenta y seis pesos en todos estos cálculos, antes bien hemos supuesto los productos actuales mayores que los verdaderos, y mucho menores los que devían haberse verificado, rebajando siempre de las partidas como se advertirá fácilmente.

Esta gran pérdida ha sido sólo por lo respectivo a Zacatecas, y bien hay seis u ocho reales de Minas de primer orden casi iguales a éste y otros treinta que cada tres componen un Zacatecas, y de los restantes compongan lo cada diez o lo que es más puntual y bien fácil averígüese el producto de cada uno en su principio, y su progreso, fórmese un estado medio, véase lo que conforme a él debían haber producido en un corriente regular por el tiempo de su decadencia y hágance cuantas rebajas se quieran todavía se hará increíble el bulto de las sumas.

Nosotros no lo haremos por no llenar de cálculos muchos pliegos. Pero bien quisiéramos que Vuestra Excelencia, el Ministerio y el Soberano mismo, tocasen con la experiencia la miseria actual de la Minería, y cuales debían ser sus frutos. Sería entonces tanto mayor la compasión, y la esperanza, cuanta es la ventaja que les llevan los ojos a los oídos. Hacemos este apóstrophe para entrar en una réplica tan especiosa, o aparente, que mucho tiempo ha tiene prevenido el ánimo de algunas personas contra las pretenciones de la Minería, fundadas en su lastimosa deterioridad.

En estos últimos veinte años, se ha experimentado aumento en la labor de la Moneda respecto de los anteriores a este período; y siendo constante, que en ella no se labra vajilla, ni otra cosa que las barras que vienen de los Reales de Minas, no es compatible la decadencia de éstos con el aumento de la labor; antes bien se arguye el de la Minería en general. Esta 
objección, que como hemos dicho, es capaz de preocupar a todos los que carecen del conocimiento práctico de este Reino, fácilmente se desvanece si se advierte siquiera entre otras razones que en los referidos veinte años ha sucedido la contingencia de haberse descubierto muchos nuevos Minerales. En el año de 46 se descubrió el Real de Bolaños, en el de 47, el de Basuchil, en el de 50 San Joseph del Oro; en, el de 51, Juchipila, en el de 52 Topago y Guadalcázar, en el de 54 Hatlaya, en el de 55, Zichu, en el de 56, Santa Cruz de las Flores, en el de 57 Palo Blanco y Boca de León todos estos Reales de Minas han comenzado (como es lo ordinario) con particular riqueza; que mucho pues que su producto agregado al de los antiguos aunque muy decadentes, haya sido bastante, no sólo a compensar la disminución de éstos, sino .a hacer la ventaja, que se ha experimentado en la labor de Moneda. Sólo en el Real de Bolaños produjo desde el año 46 hasta el de 60 de tres y medio a cuatro millones de pesos cada año en platas manifestadas al Diezmo. Pero por ventura se ha de fiar la subsistencia de la América a estos descubrimientos, que los ofrece el caso, y no los encuentra la solicitud. Para que se descubran nuevos Minerales no es menester que se arruinen los antiguos, y si a lo que éstos debían haber producido manteniéndose en un mediano corriente en el tiempo de su decadencia, se agregara el producto de los referidos nuevos Asientos, se vería que la Casa de la Moneda debía haber labrado en estos veinte años mucho mayor número de marcos que el que efectivamente se ha verificado; con que viene a ser imaginario el aumento de las Platas del Reino, fuera de que en estos últimos tres o cuatro años, ha desmerecido ya la Labor de Moneda respecto de los próximamente anteriores. Y la razón es: porque las nuevas Minas, que causaron el pretendido aumento, han sido de muy poca subsistencia, y apenas se han descubierto cuando ban faltado, de suerte que muchas veses con la noticia de las imaginadas felicidades han llegado a nuestros oídos los inútiles lamentos y lágrimas de los mismos descubridores. Un exemplar recientísimo nos ofrece el famoso descubrimiento de Boca de Leones: su primera extraordinaria riqueza y en su entera ruina se verificaron en pocos meses. Y es muy regular que assí suceda en todos los nuevos Minerales que se descubren en lo bien poblado de este Reino; porque como ya están conocidas y descubiertas las principales matrices o criadores de los Metales de Plata y Oro y sobre ellos se fundan los antiguos Asientos de Minas, es preciso, que fuera de éstos no se hallen otros de tan buenos fundamentos.

Con igual error podría pensarse (y se ha pensadq) que la ruina de la Minería resulta de haberse acabado, o consumido los Metales de Plata y Oro .0 a lo menos todos aquellos cuya riqueza fuese suficiente a de- 
jar alguna utilidad sobre los ordinarios costos de su extracción y beneficio; en cuyo caso debíamos humildemente conformarnos con los fines de la providencia. Pero bien lejos de que esto se haya verificado, muestra la experiencia que las Minas antiguas y principales del Reino conservan aún en sus profundos senos riquezas mucho mayores que las que han dado en su principio; porque aunque los Metales sólo se crían hasta una cierta profundidad, raras veces se ha llegado a ella; y cuando se agotasen es tan experimentado de los Mineros como inconcuso entre los físicos, que la naturaleza reproduce en las matrices idóneas sus preciosos frutos, después de algunos años. $\mathrm{Y}$ así no es la causa de la decadencia de los principales Reales de Minas haberse consumidos sus Metales, ni esto debe nunca temerse; sino el que hallándose ya los muy ricos en una estupenda profundidad, y acompañados de copiosísimos veneros de agua, custodios necesarios de las riquezas subterráneas, aunque éstas sean muy suficientes a compensar los ordinarios costos del desagüe y extracción, y dejan crecidas ventajas, habiéndose abandonado las Minas, y dejádose inundar hasta la boca, se necesitan para su primera habilitación cuantiosísimos caudales, de que por ahora carecen los Mineros y sus aviadores, existen también en los Minerales muchas catas (que así llaman a las Minas poco profundas) e innumerables vetas vírgenes, como por lo tocante a Zacatecas está plenamente justificado en las citadas diligencias. Y aunque sean capases de dar muchísimos Metales, son de mediana Leyes. Y así no pueden cubrir el alto precio del Azogue, Fierro, Acero, y demás Materiales, y los crecidos derechos de la plata, y el oro. De suerte que la verdadera causa de la general decadencia de la Minería consiste en que para habilitar las Minas antiguas y muy hondas, no hay caudales, y aunque pudieran darlos las muchas catas y vetas nuevas, los excesivos costos y derechos que por ahora sufren los Mineros no dan lugar a esta ventaja.

De esto Señor Excelentísimo se infiere naturalmente cuáles deven ser los medios oportunos y suficientes no sólo a evitar la última ruina de la Minería, sino a restablecerla, de suerte que dentro de pocos años vuelvan a ser sus productos iguales, cuan mayores que los de su primera opulencia. Moderar los costos de las Minas, el alto precio de sus materiales, y los crecidos derechos que sufren; podrá seguramente a este importante ramo en el estado, que hemos referido. Y como el Azogue es el ingrediente de mayor valor y consumo en los muchos Metales que con él se benefician, y la utilidad que en su venta lograba la Real Hacienda, tam crecida. Ha sido siempre un recurso muy obvio la pretención de su rebaja y parece que ha mucho tiempo que se piensa en ella. Por lo que 
sabemos en 1720 don Joseph de Lamas Sotomayor informó a Su Majestad que con vajar el Azogue a la mitad de su precio se costearía el beneficio de muchos Metales de baja Leyes y con esto se seguiría el necesario aumento de las platas y sus derechos; pero contra esto representó el Señor Veitia, primer superintendente del ramo de Azogues, pretendiendo arguir de falso todo lo informado con certificaciones de Oficiales Reales de las principales Cajas de Minería. Sin embargo en 1727, el Excelentísimo Señor Marqués de Casafuerte en junta de medios para aumentar la Real Hacienda, estimó con todos los sabios Ministros y personas muy cuerdas y prácticos que la compusieron, que el medio más eficaz para el referido fin, era la expresada rebaja en el precio del Azogue, con la resolución de esta junta, en que se propusieron poderosas razones, que a la letra se hallan en los comentarios a las Ordenanzas de Minas doctamente escritos por el Señor Gamboa,-se dio quenta a la Corte. Pero en ella no se tomó resolución. Después el Contador de Azogues don Joseph Villaseñor en unas reflexiones o notas breves a ciertas tablas aritméticas que havía escrito, pretendió probar, que era un mero error vulgar el referido pensamiento de la rebaja. Contra esto Don Joseph Fabriz apoderado de la Minería de Guanajuato, escribió un libro con el título de Apología, a que respondió con otro el mismo Contador Don Joseph Villaseñor impreso en 1742. Finalmente hasta el de 47 han salido diversos manuscritos a favor del uno y del otro dictamen. Pero de estas escaramusas no ha resultado otra cosa, que hacer célebre esta questión, sin que hasta ahora la Minería en un cuerpo haya echo recurso formal y legítimo, manifestando su miserable estado con claridad y justificación como al presente. $\mathrm{Y}$ aunque es preciso hacernos cargo de los argumentos del Contador don Joseph Villaseñor y sus aliados, procuraremos satisfacerlos con la mayor brevedad y ahorrando los muchos cálculos inútiles, y embarazosos, que en esta materia suelen formarse.

Lo primero: cree el Contador Villaseñor que acumulando gran número de certificaciones de Oficiales Reales, de las principales Cajas sitas en los Reales de Minas del Reino, podría seguir de falso todo lo que afirma don Joseph de Lamas. Y aunque no adoptamos enteramente los informes que éste hizo a Su.Majestad en la materia; algunos de sus artículos son en gran parte verdaderos. Por ejemplo: el que haya en los Asientos de Minas muchos terreros o montones de piedras con cortas Leyes de plata, cuyo beneficio hasta ahora incosteable, pudiera hacerse costeable con la baja del Azogue a la mitad de su precio; es un hecho, que fuera de que en caso necesario podrá justificarse plenamente, se viene su verdad a los ojos; porque estos terreros se forman de lo que en las Galeras de las Mi- 
nas se separa, y se arroja como inútil, y por tal se reputa todo aquello, que aún que lleve muchas partes metálicas, como que esto se hace a ojo de buen varón, no es suficiente a costear su beneficio, en que supuesto el ahorro de la saca con poca ayuda de costa, pudiera verificarse algún provecho; y que los terrenos deban ser muy grandes se infiere evidentemente de la gran profundidad de las minas, y los muchos años, que se han trabajado, estas y otras proposiciones se impugnan copiosamente, y con sólo el apoyo de certificar los Oficiales Reales lo contrario de lo que dice Lamas; pero habiendo éste informado agriamente (con verdad, o sin ella) de sus procederes, ¿cómo pueden estimarse en el asunto por unos testigos sin tacha? Y ¿porqué no se ha de sospechar, que estos Ministros quisiesen manifestarse oficiosos en la defensa del Real interés, eligiendo el seguro del partido negativo con el salvo conducto de no tener quien les contradijese? Porque no se oyó a los diputados de Minería, y se tomó informe de los Curas y Prelados eclesiásticos, y otras personas indiferentes, pues estas certificaciones serían irrefragables si tratasen de cuanto se consumía de Azogue, o cuanto producían los quintos de aquellas Cajas; como que siempre se podrían comprobar por sus Libros originales.

Lo segundo: que siendo el expendio regular de Azogues en aquel tiempo, en un año con otro, la cantidad de cinco mil quintales, sólo importaría la rebaja doscientos mil pesos y suponiendo que haya sólo cuatrocientos Mineros (porque si este nombre ha de darse a los que en los Reales de Minas sacan algunas piedras, y las venden o las benefician semanariamente, éstos son inumerables y para cada uno de ellos es grande alivio el de diez pesos) pero si se han de llamar Mineros los que trabajan Minas en corriente, estas haciendas propias, o Ingenios, y que son capaces de diezmar desde cinco mil hasta veinte o treinta mil marcos al año, estos por cierto que no llegan a ciento y fuera de eso con la rebaja de Azogues se había de expender más cantidad de este género; y así, la que se parte debía ser mucho mayor; con que le vendría a caber a cada Minero, igualados todos, o dos, o tres mil pesos cada año, que es un considerable fomento. Y aun cuando importara la rebaja solamente los doscientos mil pesos que se dise, esta cantidad debe considerarse como parte de la que se emplea en havilitación de las minas. Y ¿quién ha pensado que doscientos mil pesos de avíos anuales y perpetuos, y que nunca se habian de sacar de este comercio, no son un muy competente auxilio; aunque se destinen a toda la Minería, porque en ella con muy poco principal se suelen hacer grandes ganancias? $\mathrm{Y}$ así estos doscientos mil pesos, dentro de pocos días tal vez, se duplicarían y en otro tanto tiempo se quadruplicarán, y finalmente harían algunos millones, aunque se quitase mucho por la can- 
tidad que del principal podía perderse. Esto bien lo entenderán todos los que supieren cuánto caudal puede girarse en un comercio veloz, aunque se comience con un principal mediano.

Lo tercero: afirma don Joseph Villaseñor que las Minas, que no son muy costeables con el precio que hoy tiene el Azogue, no lo serían, aunque se les diese de balde. ¡Notable paradoja! Aunque no se percibe la razón, con que la pretende aparentar, puede formarse a su favor el siguiente paralogismo.

Por cada marco de plata que se saca, se pierde una libra de Azogue, y así a proporción; de suerte que cuanta más o menos plata se saca, tanto más o menos Azogue se consume. Luego en los Metales que tienen muy poca plata, se gastará muy poco azogue, y por consiguiente la rebaja de la mitad del precio de éste, será un alivio tan corto para el Minero que no baste a compensar los demás costos de la saca, y beneficio de estos Metales. Esto cuando más, lo que prueba es que aquellas Minas en cuyos costos se pierden más que lo que importa el valor del Azogue, que en ellas se consume, quedarían incosteables, aunque se diese de balde. Pero siempre fuera cierto, que se perdería menos, en las que se pierde tanto cuanto vale el Azogue, las cuales se harían costeables. Y en las que ahora se gana algo, sería mayor la ventaja, y muy considerable por esto, la de toda la Minería.

El Contador no se hizo cargo de esta respuesta, pero otros con alguna más sutileza replican. Que las Minas cuia pérdida excede a la cantidad de la rebaja, no se trabajarían con ello, porque todavía quedarían incosteables. Las que ahora ofrecen utilidad, pues la ofrecen, no necesi$\tan$ que se baje el precio. Con que esta providencia de baja, sólo haría trabajar aquella clase de Minas, cuya pérdida precisamente se iguala a la cantidad de la rebaja, y éstas ya se ve, que son muy pocas para que causen un alivio competente a la Minería; que indemnisen la Real Hacienda; y mucho menos para que ocasionen su aumento. Nosotros respondemos: que aun cuando ello fuese assí, los Mineros que convierten todas sus facultades en trabajar nuevas Minas, convertirán en esto la mayor ventaja que conseguirían en las lucrosas, perdiendo menos en las incosteables, les duraría el. caudal más tiempo y pudiendo trabajar siempre las que con la baja se hacían costeables encontrarían mejores Metales que las hicieran provechosas. De manera que esta succesiva transmutación de la calidad y estado de unas y otras y el más tiempo que podían trabajarse, hiciera que en todas las tres clases (y por consiguiente, en todas las Minas) se sacase más plata, y que todas ellas se habilitasen. Pero si con este y los anteriores argumentos sólo se pretendiese provar, que la 
rebaja del precio de los Azogues no es el único y total remedio de la Minería, enteramente convendríamos.

Lo cuarto arguye: que aun concedida la hipótesis, de que se consumiría un medio tanto más de Azogue, y que resultara a proporción más plata que la que hoy resulta; con sólo esta ventaja, lejos de aumentar la Real Hacienda, no sería capaz de indemnizarla de lo perdido en la baja de Azogues. A este llama el Contador, argumento hipothético; y le propone de esta manera: un Minero, se supone que gasta ahora cien quintales de Azogues gastase con la rebaja ciento y cincuenta. Computa el valor de aquellos a sesenta ducados, y el de éstos a treinta; carga en ambas partidas el monto de los derechos de la plata y conferidas las sumas, sale la Real Hacienda ventajosa (en la hipótesis de la rebaja) en dos mil y seiscientos pesos. Esto lo confiesa así el Contador; pero añade que el adelantamiento es imaginario porque si se carga lo que perdió la Real Hacienda en los cientos cincuenta quintales de Azogue, dados a treinta ducados, los cuales debían venderse a sesenta (que son seis mil pesos) quedaría perdiendo aun tres mil y cuatrocientos. Advierta Vuestra Excelencia la falacia que incluye este discurso, que a no ser tan clara, creeríamos, que el Contador, más que un alucinado, había procedido malicioso: en la suposición de valer el Azogue a sesenta ducados, mayormente cuando no debe consumirse el Minero de su argumento, más que cien quintales, ni lograr la Real Hacienda ventaja en los derechos, como que sacaría menos plata; al contrario en la otra hipótesis, sólo valiendo el Azogue a treinta ducados puede verificarse que el Minero consuma ciento y cincuenta quintales y que cause un medio tanto más en los derechos. Como pues, quiere el Contador juntar los dos casos contrarios, esto es, que consuma el Minero más Azogue, y que éste deba valer a sesenta ducados; no queriendo advertir que lo que causara la mayor saca de plata, y el mayor consumo de Azogue, es precisamente la baja del precio de este ingrediente. $\mathrm{Y}$ así el mismo arguye contra lo mismo que supone, resultando siempre cierto que en el caso de su argumento, queda la Real Hacienda adelantada en dos mil y seiscientos pesos. Nos explicaremos con un ejemplo: supongamos que un mercader, haciendo dos ventas a un cincuenta por ciento, gana en el día cien pesos. Que se le persuada que ganando un veinte y cinco sólo, haría diez ventas al día, y que en ellas quedaría por consiguiente utilizado en doscientos y cincuenta pesos. Sería tolerable que admitida esta hipótesis, respondiese el mercader que en ella quedaba perdiendo porque en las diez ventas a un cincuenta por ciento, debía ganar 500 pesos. No hay duda que se haría indigno del consejo por que debía advertir que en el caso de ganar a un cincuenta por 
ciento en el día, no podía hacer las diez ventas, sino solamente dos. Pues es lo mismo que el argumento hipotético del Contador don Joseph Villaseñor, contra el valor del Azogue.

Ultimamente se dice, en tono de represión que el precio a que se reparten los Azogues no se puede reclamar como excesivo porque está definido y determinado por la Ley Real que lo califica de moderado. Pero veamos la buena fe con que se acusa este crimen. Las palabras de las Leyes (que es la $8 .^{\text {a }}$ del título 23 libro 8 de Indias) son las siguientes: a los Mineros de la Nueva España se lleve por cada quintal de Azogue, puesto en México a razón de sesenta ducados. precio que ahora se tiene por moderado, atento a ser grandes los fletes, mermas y riesgos y otros costos que tiene, hasta ponerlo en dicha Ciudad de México. Ahora bien, esta Ley es del Reinado del Señor don Felipe Quarto (aunque con equívoco la atribuye el Contador al Señor don Felipe Tercero) y de aquel tiempo en que España se hallaba por todas partes afligida, con guerras domésticas y exteriores, la navegación para las Indias sumamente arriesgada, y los trabajos de la Mina del Almadén menos expeditos. ¿Que mucho pues, que con este aumento de costos y de riesgos se estimase por entonces moderado el precio que hoy tiene el Azogue? Así lo expresa la misma Leyes, en aquellas palabras, precio que ahora se tiene por moderado, atento a ser grandes los fletes, mermas y riesgos y otros costos. Señalando esta misma el precio del Azogue a sesenta ducados para el nuevo Reino de Granada dice que es el que tenía de costo. puesto en aquellas Minas. ¿Pero acaso los precios de las cosas no deben padecer mutación en los tiempos? En cédula de 20 de octubre de 1706 dirigida al Prior y Cónsules de este comercio, sobre que avisase a punto fijo la cantidad de Azogue que se debía remitir cada año y concurriese con dinero para habilitar la pronta remisión (que se cita y expresa en la citada junta del Exmo. Señor Marqués de Casafuerte) se afirma que el Azogue del Almadén le tiene al Rey de todo costo. puesto en Sevilla, trece pesos, no cabales el quintal, y que conducido en los navíos de Su Majestad de Cádiz a Veracruz y cargando también le transporte de Veracruz a México, no llega todo el costo a treinta pesos; con que ya en este siglo no se debía tener por moderado el precio de ochenta y dos a que se expende; pues es mayor la ganancia que la de un ciento y sesenta por ciento en un género necesario y necesario de primera necesidad.

Sólo pues, la fatal constitución de aquellos tiempos y el silencio de la Minería, digno de su fidelidad, mientras no sentía decadencia, pueden haber mantenido los Azogues en tal alto precio muy contra la voluntad del Rey; pues Su Majestad como dice el Señor Solórzano en la providen- 
cia de ellos, nunca ha puesto la mira del interés y ganancia, sino a que estén abundantes de este género los Mineros y Minerales. Porque la experiencia ha mostrado que cada mil quintales de Azogue que se consumen o reparten producen un millón de plata. Así lo dice la cédula de Su Majestad de 14 de agosto de 1610. Y por la Leyes 3 título 15 libro 6 de Indias, se manda expresamente que el Azogue que se vendiese a los Mineros se dé al precio y costo que al Rey le tuviere puesto en Potosí y en los demás Asientos de Minas por los grandes costos que tienen en su labor y para que hagan mejor paga a los Indios en sus jornales. Aunque quiera decirse que esta Leyes habla de los Mineros del Perú se responderá que es general y que no distingue y que en nosotros es igual la razón y mucho mayor el mérito y la constancia. La Leyes 4 título 20 libro 4 de Indias previene que los Excelentísimos Señores Virreyes favorezcan a los Mineros y les hagan dar los maízes de los tributos y todos los materiales de que tuvieren necesidad para el avío de sus Minas y beneficio de sus Metales a precios justos, prohibiendo en esto todos los excesos. Y como los Azogues no pertenecen más al Real haber, que los maízes de los tributos, no hay duda que el espíritu de esta Leyes y sus laudables fines comprehenden a este ingrediente, siendo el más necesario para sacar las platas de su beneficio, el cual se expende con una utilidad a favor de la Real Hacienda, que por una parte es excesiva respecto de los costos que tiene, y por otra parte estorba los progresos de las Minas.

Nosotros no aseguramos que sólo con la baja de los Azogues, se multiplicará el ramo de los derechos. Su aumento es probabilísimo, y aunque no lo podemos afianzar, porque también depende de otras circunstancias; pero sí afianzamos que no se perderá nada y por el contrario sí se ha perdido mucho y se perderá muchísimo porque cada año será mayor la decadencia de los Reales de Minas y menor el producto de platas, y el consumo de Azogues, como se va experimentando. Y sin embargo de que no tenga la culpa de esto el alto precio de este ingrediente, no puede negarse que su rebaja es uno de los remedios que hay; y para que esto se conozca con evidencia, notémoslo sólo en Zacatecas. Ya vimos que en estos últimos doce años se han dejado de consumir diez mil quintales de Azogues que valen ochocientos y veinte mil pesos; si éstos se hubieran consumido rebajándoles la mitad de su precio, no se hubieran perdido más que cuatrocientos y diez mil pesos, con que se hubiera evitado la pérdida de lo restante y cuanto más en el producto de los derechos, lo veremos después pero ahora, entiéndase la reflexión sobre todos los Reales de Minas que benefician con Azogue, en los cuales respectivamente se verifica lo mismo. 
El haberse de consumir como hemos dicho, mucha mayor cantidad de Azogue, supuesta la rebaja de su precio, da ocasión a otra providencia que hace en mucha parte precisa, la eficacia de este remedio. No es necesario ponderar el embarazo y dificultad que se añade a la extracción de las platas y del oro sobre las que le son naturales, con haber de traer el Azogue, nada menos que desde el otro continente. La pérdida de una gran cantidad de este ingrediente y la escasez que en alguna ocasión ha hecho preciso el tomarlo a precios carísimos de Alemania y de Oriente, dieron motivos a subir el del Azogue, que ha causado tan grandes perjuicios. Las guerras, los sabidos riesgos de la navegación y las contingencias de la $\mathrm{Mi}$ na del Almadén (que es Mina, como las demás) continuamente amenazan la falta de la mayor parte de la plata que se saca de este Reino de Nueva España, no sólo para la vez que escasea, o que enteramente se carece de este ingrediente, sino también en mucha parte para en adelante porque cesando con este motivo el trabajo de las Minas que necesitan un continuo desagüe, se inundan hasta la boca, y después no es posible su habilitación sino a costa de crecidos caudales; de suerte que las más de ellas se quedan por esta causa enteramente inhabilitadas. Todavía siente la Minería el detrimento que padeció con la última escasez de Azogues de los años de 58 y 59. En el famoso Real de Guanajuato, se hizo cómputo de que había dejado de haber la Real Hacienda en aquel tiempo más de setecientos mil pesos; y aún se experimenta en él este golpe, estimándose como una de las causas principales de su decadencia, como lo representó entonces el Cabildo y Regimiento de aquella Ciudad al Señor Superintendente de Azogues y parece que se dio cuenta a Su Majestad de ello.

Si la naturaleza no hubiere criado en este fertilísimo Reino tan apreciable Mineral, veneráramos este acuerdo de la alta providencia, como uno de aquellos vínculos de la sociedad universal que hacen necesaria la dependencia entre las Ciudades, los Reinos y demás partes de la tierra. Así se pensaba ahora dos siglos; pero la experiencia ha hecho conocer que en este país se hallan abundantes Minas de Azogues, como de todos los Minerales. La casualidad sola, sin auxilio de la industria, las ha encontrado en Chilapa, en sierra de Paños, en los cerros del Carro y Puacho, en Cuernavaca, en Temascaltepec, en Guastla, en San Luis de la Paz, en San Luis del Potosí, y en algunas otras partes. Recientísimamente en Guanajuato, en tiempo de la referida escasez, el Regidor de aquella Ciudad don Agustín de la Torre, descubrió una veta de Azogue que examinada de orden del señor superintendente de este ramo y de cuenta de dicho regidor, decidieron los peritos su formalidad y abundancia; y en efecto, todas estas Minas, aun a poquísima profundidad, ofrecen el Azogue con tal copia, que 
trabajadas de cuenta del Rey, o comprando a los particulares, le tendría menos costo que el que se trae del Almadén; y como están repartidas con tan bella distribución por todo el Reino, se escusarían a los Mineros los costos de fletes y mermas que son crecidísimos en la vasta extensión de esta América; de suerte que en algunas partes, llega a valer la libra a dos y tres pesos, y hay algunas partes tierra dentro donde se pagaría a cualquier precio como lo hubiese; dejándose de sacar mucha plata y muchísimo más oro, por su absoluta carencia o carestía.

Hay ciertamente muchas Minas de Azogue; pero no basta el que se sepa que las hay, para que puedan surtir de este ingrediente cuando falta el que se trae de la Europa. Ya se ve que en estos casos, se suele ocurrir a ellas como a el último asilo; pero mientras se habilitan las Minas, se aprende, y se pone en corriente su beneficio, se pasa el tiempo bastante para que perezcan las de plata; y los particulares se guardan bien aun de dar estos primeros pasos porque así que viene el Azogue de España, les hacen tapar las Minas y quedan perdidos. Las providencias del Gobierno, ya se ve, que no pueden ser tan promptas para que se trabajen de cuenta de la Real Hacienda, de un modo que se socorra en tiempo la necesidad; y los Pueblos, y dueños de haciendas, en cuyas tierras suelen hallarse las Minas, temiendo la incomodidad y perjuicio que podía resultarles de esta providencia, toman el partido de desacreditarlas, o el que mejor les parece para estorbar que se trabajen. Por cuyos motivos creemos que esto no se podría conseguir siendo por otra parte imponderablemente útil y necesario, sino permitiendo y aun estimulando desde ahora a los particulares para el descubrimiento y labor de Minas de Azogue, vendiéndolo a Su Majestad de cuya quenta se repartiese como se hace con el salitre y el Azufre, respecto de la Pólvora y otros géneros estancados. Ni por esto se inutilizaría el que se saca de la Mina del Almadén, porque debiéndose consumir (como es preciso, supuesta la rebaja) mucha mayor cantidad de Azogue, se podría repartir el expendio de suerte que la mitad, o dos tercias partes se consumieran del del Almadén, y lo restante del de Nueva España, limitando para éstos el trabajo de las Minas, en caso necesario y ampliándolo en el de faltar o escasear enteramente el de Europa.

Sin duda que por estos fundamentos, la Ley 4 título 19 Libro 4 de Indias, lejos de prohibir el descubrimiento y labor de las Minas de Azogue, no sólo lo permite sino que encarga a los Excelentísimos Señores Virreyes que pongan todo cuidado en que de las que hubiere noticia en cualquiera parte de este Reino, se descubran y beneficien y hagan a los que las descubrieren $y$ labraren las conveniencias que les parecieren. $Y$ en las Leyes $2 \mathrm{I}$ título $\mathrm{X}$, libro 6 se previene que advirtiendo la necesidad de 
trabajar las Minas de Azogue para beneficiar las de plata, los Excelentísimos Señores Virreyes procuren avecindar a los Indios cerca de ellas, por ser precisa su industria y trabajo, cuidando de su buen tratamiento y paga. $Y$ aunque por informe del Señor Veitia se mandaron cerrar las Minas de Cuautla y de Amilpas en Real Cédula de 5 de julio de 1718; fuera de que las razones de dicho informe se hallan enteramente convencidas en la Junta de medios celebrada el año de 27 por el Excelentísimo Señor Marqués de Casafuerte; conviniendo con graves fundamentos todos los concurrentes en la necesidad de esta providencia y en que se diese cuenta sobre ello a Su Majestad la referida Real Cédula y la otra del año de 30, solamente han sido aprobativas de lo hecho, e informado por los superintendentes y meramente provisionales para el caso particular, tiempo y circunstancias en que se expidieron; y por esto, ni se expresa en ellas, ni puede sospecharse haber derogado las citadas Leyes fundamentales del Reino; a más de que en Real Cédula de 14 de marzo de 1742 posteriormente a las referidas, el Señor Don Felipe Quinto se sirvió aprobar lo resuelto por este Real acuerdo, en la escasez de Azogues de aquel tiempo, y prevenir el trabajo de algunas Minas de este ingrediente, remitiendo el reglamento de la del Almadén, como se alega por el cabildo y regimiento de la Ciudad de Guanajuato en las diligencias arriba expresadas.

Igualmente necesario y provechoso es al gremio de la Minería, el que el Azogue no se dé ni reparta al fiado como hasta aquí se ha hecho, sino que se venda al contado y por menor. $\mathrm{Y}$ aunque pueda parecer que en lo primero, se les hacía beneficio y que acaso por esta razón, se habrá practicado así, es ciertísimo que es una de las cosas que ha ocasionado mayor perjuicio y daño a los Mineros; porque cargándose con facilidad y gravemente del crédito de Azogue, se les imposibilita de suerte la paga que no pudiendo hacerla, aun después de unos a otros plazos, se ven precisados los Ministros de Real Hacienda a ejecutarlos para su resguardo, en el cobro de lo que les está encargado. Y no teniendo por lo regular, otros bienes que las mismas Minas o ingenios de moler Metales, se hace necesario (aunque en esto se proceda con el orden que previene la Ley del Reino) trabar ejecución en ellos. $\mathrm{Y}$ al instante cesa este motivo su corriente, parando las haciendas y el desagüe de las Minas que para siempre pueden quedar inundadas, como sucedió en Zacatecas con todas las principales de aquel Real; siendo ésta una de las mayores y más conocidas causas de su ruina. Es imponderable el perjuicio que de esto ha resultado; pero no es el único. También se sigue la dificultad de hallar avío porque teniendo preferencia (como es justo) el crédito de la Real Hacienda contra los particulares, aunque sean últimos refaccionarios, viene con esto a ser la de- 
pendencia de Azogues y aun la facitídad de contraerla uno de los mayores retayentes para la habilitación de la Minería. Y así renuncia este beneficio, que por el contrario, con tanto anhelo se ha pretendido en el Perú, como refiere Escalona ' facilitando con esta renuncia la baja de Azogues; porque si se reflexiona en lo mucho que por darlo al fiado se ha perdido de su producto, bajándolo de su precio, se advertirá a cuanto menos se pudiera haber expendido de contado, de manera que acaso se ha perjudicado la Real Hacienda y la Minería con lo mismo que una y otra podían estar muy ventajosas.

Con estas circunstancias, Señor Exmo., sería la rebaja de precio en el Azogue, un media de bastante eficacia para evitar lă precipitada decadencia de las Minas; pero es preciso decir que con esto solo, no se puede estorbar del todo, ni remediar enteramente el daño: porque hay muchos, y en un tiempo riquísimos, Asientos de Minas, que abundan sólo en Metales plomosos y de fundición; de suerte que para ellos de ningún alivio sería la baja del precio del Azogue, estando por otra parte en igual decadencia que los que más necesitados como se verifica en Chihuahua, $\mathrm{Zi}$ mapán, el Mazapil y otros muchos donde no conocen los Metales, ni han menester su beneficio; y fuera de esto aun los que lo usan y necesitan, sólo quedarían en parte remediados con la expresada rebaja; porque en estos mismos Reales de Minas, se sacan muchos Metales que precisamente deben beneficiarse al fuego, por ser su plata negra y gruesa, y acompañada de tales malicias o medios Minerales, que no se puede poner en disposición de unirse al Azogue, y aun en los Metales de este beneficio suele ser necesaria la fundición; los asientos, rebalses o polvillos, de suerte que el haber propuesto nosotros antes de la baja de los derechos, la del precio del Azogue, ha sido porque consistiendo ésta sólo en tener menos ganancia en ellos la Real Hacienda, se hace más fácil, y excusa el que la de los derechos sean tan grandes, como era necesario para impedir la gran ruina de la Minería. Y es cierto que combinadas ambas, no sólo serían capaces de evitarla, sino de restablecerla enteramente y de ocasionarle a la Nueva España y a la Monarquía su mayor opulencia. Esto Señor Excelentísimo, está fuera de toda disputa. De suerte que aun los más opuestos a la rebaja del precio de los Azogues confiesan que la de los derechos sería un remedio de mayor eficacia con que deben confesar que las dos juntas causarían la felicidad de entrambos Reinos.

Bien vemos, que la razón más poderosa que puede haber y que acaso hasta hoy ha habido, para no determinarse la aplicación de uno y otro

1 Gazophilatti Regii Perubici, Libr. 1, capit. 45 per totum. 
remedio, es el que la Real Hacienda entra perdiendo de contado una gran parte de caudal, cuando lo que se promete de su ventaja y aun de su reintegro, puede tenerse por probable. Pero además de que nosotros no proponemos estas providencias como un arbitrio por aumentar el Real Erario, sino que las pedimos como un remedio necesario para su conservación y para impedir la última ruina de la minería de Nueva España, es ciertísimo que más han perdido y perderán los intereses del Rey, no haciendo las rebajas del Azogue, y de derechos, que concediéndolas. Y vamos a demostrarlo. No es dudable, que si estos remedios se hubieran aplicado en Zacatecas, desde el año de 1732, que es la época de su decadencia, se hubiera evitado ésta, y manteniéndose el Real de Minas en aquel međiano corriente que conservó por 180 años como se ha expresado antes.

No creemos, que en esto pueda ponerse la menor duda, porque para ellos no era necesario algún particular aumento de sus Metales, ni otro acontecimiento extraordinario. Del cálculo, que antes formamos por lo que consta de los libros de aquellas Cajas, resulta que ha perdido la Real Hacienda en estos 34 años, sólo en los derechos de las platas de Zacatecas, cerca de siete millones de pesos; y si de éstos se hubiera rebajado desde entonces la mitad, siendo el total de lo producido y debido producir ocho millones, sólo se hubieran perdido cuatro; luego, hubieran dejado de perderse dos millones, y también los dies y seis correspondientes, que el perdido caudal del público hubiera causado en derechos de comercio. Con que si los veinte y cinco millones que efectivamente ha dejado de haber la Real Hacienda, como arriba computamos, sólo se hubieran perdido siete (y aun mucho menos) pues también vimos que con la baja del precio de Azogues, se hubiera evitado gran parte de la pérdida que por lo tocante a este ramo se ha verificado en aquel Real. Y así es evidente que muchísimo más ha sido perdido y perderá la Corona en no hacer las pretendidas rebajas, aunque éstas le parezcan más sensibles, que en hacerlas.

Y no sólo perdiera menos, sino que lejos de perder algo de lo que se rebajase, abanzaría mucho más; porque el genio de los hombres es tal, que unos por la codicia, y otros o los más por necesidad, y falta de arbitrios en la América para buscar lo necesario, que en cuanto perciben cualquiera razón que haga más probable la ventaja o que deje menos expuesto el empleo de las Minas, se dedican todos a su laborío. Esto se experimenta siempre que a México, o a otros lugares llega noticia de alguna particular bonanza. Ella atrae todo el comercio, mueve y alienta a la comarca. Cuando se descubrió Boca de Leones, no sólo se llenaron los caminos de recuas cargadas de fardos, y todo género de efectos, sino que distando de esta Ciudad más de 200 leguas, vimos salir a muchos y sin dinero; de 
suerte que en pocos días se formó allí un numeroso Pueblo de Gentes aunque portátil.

Como la concesión de estas rebajas fuera equivalente a una bonanza general y perpetua, que es la más segura prenda de la mayor felicidad y menor riesgo de las Minas, faltarían hombres en este Reino para trabajarlas, creciendo de día en día el producto de sus frutos, cuanto no cabe en la ponderación. Aunque se perdiesen algunos Mineros (que fuera difícil, pues con estos auxilios, apenas habría Metales incosteables) ellos no dejarían de sacar plata. Y para la Real Hacienda, lo mismo es que le haya costado a cinco o a diez pesos el marco, como siempre tenga este gremio un común apoyo de subsistencia. De aquí resultaría el necesario aumento de los derechos de la plata y del oro, y universalmente el de todos los que produce el Reino, porque éstos dimanan de los giros que hace en él la moneda, y por último el de los que se perciben en Cádiz. De manera que únicamente con rebajar el precio de los Azogues y los derechos de los Metales, crecen, no sólo ellos mismos, sino también de los tributos, por la mayor población: las alcabalas por el mayor comercio; los estancos, por el mayor consumo; y en una palabra, todos los ramos de la Corona Real; de suerte que perdonando la mitad de aquéllos, fácilmente podrían duplicarse todos éstos; siendo ésta una sangría, o por mejor decir, una dieta, no tan sólo necesaria para la salud de la América, sino que ciertamente promete el vigor, y robustez que necesita el cuerpo de la Monarquía, para conservarse.

Pero si estas razones, las que otras veces se han producido, y las que fácilmente se ofrecen meditando en el asunto, no se estiman por bastantes a persuadirlo, permítasenos Señor Exmo., en obsequio de la verdad, en cumplimiento de nuestra diputación, y en el de los vínculos de nuestra Corona, permítasenos pues decir, que las providencias que pide la Minería le son, y han sido debidas siempre de Justicia. En cuanto al Azogue, ya está bastantemente demostrado. ¿Porqué pedir que un género necesario, cuya utilidad en su venta, es exorbitante, respecto de los costos que tiene, o de los que debía tener si se extrajese de este Reino, y se reduzca a su justo precio, siendo esta la voluntad del Rey, y mandándolo las Leyes, ¿quién puede dudar que es de justicia? En cuanto a la rebaja de los derechos, lo probaremos con dos razones, que a nuestro parecer son decisivas, concluyendo con ellas esta prolija aunque importante representación de la Minería de este Reino.

La primera es que no pide en esta rebaja alguna merced, o gracia, acuerdo o providencia; que no le esté concedida muchos años ha, por derecho. Entre las Leyes o Ordenanzas para las Minas, la 76 de las insertas 
en la Ley 9, título 13 Libro 6 de la Recopilación de Castilla, edición de Madrid de 1742, previene: Que por cuanto en las Minas viejas, de treinta o cuarenta estados de hondo. hay mucho más costo para sacar las aguas. tierra y Metal y meter en ellas la madera. y pertrechos necesarios. que en las otras Minas, que tienen menos hondura, por cuya causa muchas veces viene a ser más la costa que el provecho que de ellas se saca y que en estas tales Minas no podrían los dueños pagar tantos derechos. y ser justo que en estas tales, haya moderación. Cuando lo tal acaezca. y constare al Administrador General que la Mina vieja. por ser honda. o por otras causas, viene a ser tan costosa que casi al dueño no le es de provecho. envió particular relación de ello. con su parecer al concejo. juntamente con la averiguación y que se vea y determine este punto con mucha brevedad. Toda la Minería de Nueva España se halla en este caso. La causa universal de su decadencia consiste en que las Minas principales están inundadas, y con mucho mayor profundidad que la que la Leyes tiene por suficiente; y las demás por otras causas vienen a ser tan costosas, que casi al dueño no le son de provecho. Por lo tocante a Zacatecas, consta de las citadas diligencias que en sus Minas antiguas no sólo se halla la profundidad de treinta o cuarenta estados que expresa esta Leyes, sino de sesenta, ochenta y también ciento. De los más Reales de Minas, es notorio y se justificará plenamente; con que no se pide otra cosa, sino que se aplique la sabia, justa y bien premeditada determinación de las Leyes. Estas no miran si en esto ha de perderse o aventurarse parte de la Real Hacienda, si al contrario por este medio se ha de aumentar el ramo de los derechos de la plata y oro; sólo atienden a la necesidad de los vasallos y a la conservación de las Minas, estimando en estos casos por justa la moderación de los derechos.

Y con razón, porque la concesión que hace el Príncipe del dominio de los Metales a los vasallos que los sacan es de parte de ellos, onerosa pues que de su cuenta y riesgo verifican la saca y existencia útil de la plata y oro; y respecto de la Corona, es lucrativa, porque el quinto, diezmo u otro cualquiera caso que perciba, siempre es libre de costos y peligros. $\mathrm{Y}$ así en el caso de haber crecido estos costos y peligros, es tan de justicia la moderación de aquella parte, como la que del canon o merced, debe hacer en los años estériles el cobrador del fundo fructífero, y de otras composiciones establecidas por derecho. Es también necesaria, porque supuesto que unos frutos tan útiles, no son abandonables por el estado y que por otra parte, su adquisición es tan peligrosa, y de sumo costo, que a la Real Hacienda nunca le fuera conveniente, ni posible intentarla por sí mismo, no queda otro recurso, sino que la hagan los particulares, reportando costos, exponiéndose a los peligros, sujetándose a justas condicio- 
nes, y dándole al fisco una parte, que nunca será pequeña, mientras estuviere exenta de todos gastas y contingencias.

No son nuestras, Señor, estas razones. Son muy obvias en la jurisprudencia y los autores. Y siempre las ha tenido presentes la equidad de nuestros soberanos, aun para expedir las providencias necesarias, a fin de cobrar lo adeudado por Azogues, que tan de justicia se les debe; mandando y exhortando siempre a sus Ministros que verifiquen el cobro con la mayor suavidad, moderación y prudencia. Entre muchas, sobresale la Real Cédula, dada en el Pardo, a 18 de febrero de 1608, dirigida al Marqués de Monteclaro, en la que, con otras, son de ponderar estas expresiones: Porque si no se usa con ellos, de alguna equidad o comodidad, no podrán pagar lo que deven del Azogue que se les fía. que es cada año más de cuatrocientos mil ducados, y las causas que hay para ir sobrellevando, son justas: $y$ aunque parecen de gracia, resulta en utilidad $y$ aumento de mi Real Hacienda, consideradas las grandes costas que les tiene a los Mineros, el beneficio y labor de Metales que apenas sacan su caudal.

La segunda razón consiste en que la expresada rebaja de derechos se le debe a la Minería de Nueva España, por vía de justa compensación. No alegamos para esto, el que haviéndose subido el precio del oro en las nuevas Ordenanzas de la Casa de Moneda, y pagando en su valor los derechos de este Metal, respectivamente se han grabado: ni el que, desde que se bajó la Leyes de la moneda de 11 onzas y 4 granos, a la de 11 onzas, componiendo cada 67 marcos de ésta, 66 de aquélla se ha pagado un real más por el derecho de señoreaje en cada 67 marcos de la Leyes actual; ni el que pagando con separación los Mineros sus derechos al Ensayador en los ensayes de oro, se les cobra aparte sin embargo en este Metal, el uno y medio por ciento de fundición. ensaye y marca; ni el que también en la plata, pagado ya el ensayador, se cobra el une por ciento de este título. Y haviéndose destinado en el siglo pasado para satisfacer la pérdida de un navío de Azogues, que importó medio millón de pesos, como informaron al Señor Veitia los Oficiales Reales de Guanajuato, y después de ver en el libro del Contador don Joseph Villaseñor, se cobra todavía, y se han cobrado, después de satisfecho como lo está este quebranto que no sera de cuenta de los Mineros, y más de cuatro millones de pesos. Aunque todos estos reclamos importan grandes sumas, la Minería por ahora y sólo hace esta insinuación de ellos a Vuestra Excelencia, no insistiendo más que en el que se sigue.

Perteneciendo sólo a los Príncipes y Señores Soberanos el derecho o facultad de batir moneda, para que los particulares pudiesen hacerlo de su cuenta, como lo hacían en España y con este Reino, entregando en pasta 
su plata al tesorero, y demás oficiales de la Casa de Moneda, que después se los volvían en esta especie, se estableció por las Leyes que en debido conocimiento del señorío, pagasen fuera de los costos, y derechos de tesorero, y demás empleados en la casa un real en cada marco de Leyes de moneda, que por esto se llama señoreaje o monedaje. De suerte que en no labrándose de cuenta de los particulares, sino de Su Majestad como ha sucedido desde el año de 32, cesa enteramente el título y causa de la exacción de este derecho, esto es constante, para que lo expliquemos mejor, es necesario arvertir que anteriormente se sacaban en la moneda de cada marco de onze dineros y cuatro granos. sesenta y siete reales; de ellos tres eran para los costos y oficiales; del señoreaje; y sesenta y tres para el dueño de la plata; pero concertándose por Asiento la labor de la moneda, en este caso previene la Leyes 8 título 23 Libro 4 de Indias, que ha de quedar incluido el señoreaje y monedaje en aquellos tres reales. De tal manera que los dos sean para los costos y costas, y el otro para el señoreaje.

Ha 35 años, Señor Excelentísimo, que en México no se labra la moneda de cuenta de particulares, sino de la de Su Majestad; hasta ahora cuatro años, por Asiento y después por administración. De cada marco de plata de onze dineros, se sacan ocho y medio pesos o sesenta y ocho reales. En sesenta y cuatro y dos maravedís, se le compra al Minero, y los restantes tres reales y 32 maravedís, quedan para los costos (que son muy cortos) y a favor de la Real Hacienda. Pero ya antes los Oficiales Reales han cobrado con separación, un real por cada marco de 11 dineros; siendo así que conforme a la Leyes, debía quedar incluido en los cuatro reales de la ventaja de la labor; por lo que es ciertísimo, que el real del señoreaje se ha exigido indebidamente desde el referido año de 32. Y haviéndose labrado desde entonces más de cuarenta y dos millones de marcos de once dineros, importa lo cobrado por este título, más de cinco millones doscientos y cincuenta mil pesos, sin incluir el oro en este cómputo.

No intenta por ahora la Minería, esta justa repetición por una formal demanda; ni ha hecho hasta el presente estos reclamos aunque legítimos; ya por contemporizar con las necesidades de la Corona; ya principalmente porque los Mineros no saben animar la voz de la queja, sino es en la aflicción de su última ruina, o con el espíritu de su lealtad en prevenirla. Pero si las razones que se han expuesto la experiencia de la gran ventaja que ha resultado con haber reducido el quinto al diezmo, y la de la rebaja de Azogues y derechos verificada en Guatemala, por cédula de 1738. Con lo demás que ahora, y otras veces se ha producido, no es bastante para asegurar el que la Real Hacienda no perderá nada en conceder las referidas providencias: afiáncelo esta cantidad, y la importancia de los ex- 
presados reclamos, que por tan justos títulos pertenece al derecho de la Minería. Esto bien puede cubrir la experiencia de algunos años y ella dará a entender cuánto se aumenta el bulto de los inconvenientes, y los riesgos en las distancias de mera especulación. No sale navío alguno del puerto a quien no amenazen las borrascas, los incendios, las hambres, los enemigos y piratas con mortales peligros; y sin embargo en la navegación se libra sin temor al comercio la substancia de todas las naciones.

Con esto (Señor Excelentísimo) hemos manifestado a vuestra Excelencia el presente lastimoso estado de la Minería, sus causas, y sus efectos, y que los Reales de Minas principales, antiguos, y más bien fundados, como Zacatecas, están en punto de perderse. Cada día es mayor su ruina, y cada instante, menos eficaz, y más dificultoso su remedio. También hemos propuesto los medios que para evitarla y aun restablecerla con ventaja parecen las proporcionados, y suma lo son: $10^{\circ}$ reducir el precio de los Azogues a 40 pesos (que en Guatemala se bajó a 30 sólo por adelantar un real de Minas) permitiendo y promoviendo en el Reino la saca y beneficio de este ingrediente. $2 .^{\circ}$ reducir el derecho del diezmo a la veintena, quedando enteramente abolidos, los del uno por ciento y señoreaje. Estos medios, bien pueden parecer difíciles, pero ellos son necesarios para la subsistencia de aquel nervio principal (como dicen las Leyes) de que resulta la conservación de aquellos y estos Reinos, convenientes al mayor aumento del Real Erario, y sobretodo, justos y debidos de derecho, a la Minería. La notoria aplicación y zelo de Vuestra Excelencia a todo lo que es servicio del Rey, bien y remedio de la Nueva España; la del Señor Visitador General, que sabiamente estudia también en la combinación de los intereses del Príncipe y del vasallo, punto en que consiste toda salud del Público; y últimamente las amplísimas facultades de Vuestra Excelencia y los particulares encargos del Señor Visitador General en orden al arreglo y aumento de los ramos de Real Hacienda: todas estas felices concurrencias hacen Señor Excelentísimo, la oportunidad de nuestros ruegos.

A Vuestra Exccelencia rendidamente suplicamos se sirva de proveer lo qque le pareciere más conveniente, que en Justicia pedimos, Juramos en forma y en lo necesario.

México, 2 de noviembre de 1767. Don Juan Lucas de Lazaga. Don Joseph de Laborda.

Nota. A consecuencia de esta representación se hizo presente por dichos señores a Su Majestad el estado de la Minería del Reino y en este año de 1768, ha concedido la baja de una cuarta parte en el precio de los Azogues. Esto es, en México se vendía antes cada quintal a 80 pesos y ahora se vende a 60 pesos por virtud de la Real Orden. 